Transportation Research Forum

Book Review: All Roads Lead to Congress: The $\$ 300$ Billion Fight Over Highway Funding

Book Author(s): Costas Panagopoulos and Joshua Schank

Review Author(s): Daniel Dornan

Source: Journal of the Transportation Research Forum, Vol. 47, No. 1 (Spring 2008), p. 121-123

Published by: Transportation Research Forum

Stable URL: http://www.trforum.org/journal

The Transportation Research Forum, founded in 1958, is an independent, nonprofit organization of transportation professionals who conduct, use, and benefit from research. Its purpose is to provide an impartial meeting ground for carriers, shippers, government officials, consultants, university researchers, suppliers, and others seeking exchange of information and ideas related to both passenger and freight transportation. More information on the Transportation Research Forum can be found on the Web at www.trforum.org. 
Panagopoulos, Costas, and Schank, Joshua. All Roads Lead to Congress: The \$300 Billion Fight Over Highway Funding. Washington, DC: CQ Press, 2007. ISBN 0-87289-461-4

\section{All Roads Lead to Congress}

\section{by Daniel Dornan}

All Roads Lead to Congress is a detailed examination of the deliberative process of crafting, recrafting, and passing the Safe, Accountable, Flexible and Efficient Transportation Equity Act - A Legacy for Users (SAFETEA-LU). The book chronicles the daily, weekly, monthly, and yearly struggles in Congress between May 2003 and August 2005 that caused this latest reauthorization of the National Highway and Defense Act of 1956 to be the most controversial and delayed (by two years) surface transportation funding bill ever.

The book is well written by authors Costas Panagolopoulos and Joshua Schank who maintain the interest of the reader through a combination of process narrative, supporting statistics, and provocative implications. Both authors are former Congressional fellows who worked in the office of Senator Hillary Clinton during the time of SAFETEA-LU's development. Panagopoulos is currently an assistant professor of political science and director of the Center for Electoral Politics and Democracy and the Master's Program in Elections and Campaign Management at Fordham University. He is also a research fellow at the Institute for Social and Political Studies at Yale University. Schank is director of transportation research at the Bipartisan Policy Center where he is currently directing a national transportation policy study.

The combination of a political scientist and urban planner who served as fellow in Senator Hillary Clinton's office enables the narrative to go beyond merely recounting the events that led to the passage of SAFETEA-LU. Their respective backgrounds enable the authors to comment on the theoretical implications of the process for both the legislative authors and administrative implementers of the bill, as well as the prospects for the next reauthorization effort.

Panagopoulos and Schank employ a chronological case-study approach that recreates the events leading up to and underlying the many false starts and twists and turns characterizing the formulation and passage of appropriations bills, especially those the size of SAFETEA-LU, which ultimately appropriated \$286 billion for the period 2005 to 2009. They meticulously chronicle the major players and events that took place between the May 2003 introduction of the Administration's first version of the bill (SAFETEA 2003) and the Presidential signing of the final bill (SAFETEA-LU) in August 2005. Because the narrative is drawn primarily from the experience of the two authors and selected Senate and House committee staffers, the book sheds light on a political process usually not exposed to public scrutiny.

Because the book is told from the perspective of Congressional staffers who make up much of the cast of this legislative melodrama, the maneuvering by other key stakeholders who were also involved in the process receives less emphasis in the narrative. These stakeholders include staff from the Administration, United States Department of Transportation (US DOT), American Association of State Highway \& Transportation Officials (AASHTO), American Road \& Transportation Builders Association (ARTBA), and various user, labor, and provider groups. Each of these groups pressed Congress to finalize the bill in a timely manner, especially given the declining state of the economy as the deliberations stretched into 2005.

In All Roads Lead to Congress, the authors provide a primer on the congressional formulation of appropriations bills and describe in detail the respective roles the various players in the process assume, especially staffers of powerful committee chairpersons and members of both House and 
Senate. They also explain the different rules and their implications for bill deliberations between the House and Senate, and how the entire process eventually comes together through reconciliation of House and Senate versions by a conference committee composed of key members and their staffs from both House and Senate. The narrative discusses various deals made to gain member support as the mark-up and reconciliation process proceeded, and the political maneuvering used to squash unpopular provisions or to promote desired features of the bill. This discussion illustrates the power of minority members whose votes can be gained through accommodation by the majority leadership. The end result is an appropriations bill that benefits almost everyone involved in the process, provided there is adequate funding to support the program size stipulated in the legislation.

In the book, the authors discuss the burgeoning size of staffs serving Senate and House members and the various committees, which has added even more complexity to the process. The authors take particular aim at the rapid growth of project earmarking, where individual members of Congress designate "Projects of National Significance" to benefit their congressional district and/ or major contributors. They also discuss how the volume and value of project earmarks, especially large project earmarks that benefit the districts of committee chairpersons, might have influenced the succeeding mid-term elections in 2006, when the majority party in both houses of Congress became the minority party. As a result, the leaders of important transportation committees switched from majority to minority status, hence changing the composition and policy priorities of the very committees that will begin developing the next surface transportation funding bill, due in 2009.

The authors point out various flaws in this process and their implications, particularly when the topic (surface transportation) is not a high political priority at the national level, and especially when the appropriation levels cannot be obligated in later years of the bill because of less-thanexpected revenues from motor fuel taxes whose Federal rate per gallon has not changed since the mid-1990s. They recognize the threat to the nation's mobility and competitiveness in the global economy resulting from the following conditions:

- Obligation authority diminishing relative to appropriation levels promised by SAFETEALU;

- Requirements for surface transportation infrastructure increasing faster than available funding; and

- Escalating costs of materials needed for surface transportation projects.

All Roads Lead to Congress examines the 27-month effort to find common ground among members of Congress, led by member and key committee staffs, and the White House. For cynics, the book illustrates the extent to which the surface transportation reauthorization process has become tainted by self-interests, petty rivalries, party politics, and the absence of a national vision and emphasis on surface transportation facilities and operations. Through the book, the authors send a strong message to the two congressionally-established commissions ${ }^{1}$ studying national transportation policies and funding strategies, the stakeholders of the process both inside and outside Congress, and the public. That message is that the continued or further politicizing of the surface transportation funding appropriation process will ultimately lead to a breakdown in the entire program and the loss of public confidence in the Federal-Aid Trust Fund and the Federal surface transportation programs it supports.

For those interested in the inner workings of Congress in developing and approving appropriation bills, All Roads Lead to Congress provides an excellent characterization of the process, the players, and what is required to produce a bill that is acceptable to both houses of Congress and the President. The book portrays the heroic and the sometimes shameful behavior of certain participants, focusing much of the criticism on the majority party and its respective committee members. This is of little surprise given the office in which the authors served as fellows and the fact that the majority party at the time held all the top committee positions and were in the strongest position to influence the reauthorization process and dictate much of its outcome. 
Panagopoulos and Schank have provided an insider's view of this power, money, and influencedriven process. Regarding SAFETEA-LU, All Roads Lead to Congress paints a sobering picture of the legislative process and offers little hope that the declining strength of the Federal-Aid transportation program can be reversed by Congressional action in the near future. Indeed, after reading the book, perhaps SAFETEA-LU would have been better named: "The Bill to Nowhere - A Legacy for Losers." One can only hope that by revealing the glaring flaws in the surface transportation funding reauthorization process the book will cause transportation stakeholders and the public to gain sufficient understanding to demand fundamental change in the political processes that produce the nation's surface transportation and other major appropriating legislation. If more people understood what really happened to produce SAFETEA-LU, there might be greater public pressure to take corrective action before the U.S. surface transportation system can no longer adequately support our nation's global economic competitiveness, national defense, or homeland security.

I strongly recommend this timely and informative book to professionals in the surface transportation community, stakeholders in the nation's surface transportation system, legislators at both federal and state levels, and those in the general public who would like an entertaining expose of the convoluted process that Congress employs to develop and pass appropriation bills. The contents of the book will be of particular interest to those involved in helping to define the longterm vision of the nation's surface transportation system and the programs and strategies required to achieve that vision.

\section{Endnotes}

1. The National Surface Transportation Policy and Revenue Study Commission; and The National Surface Transportation Infrastructure Financing Commission.

Daniel Dornan, P.E., is a director in the State \& Local Government Advisory Services Practice of KPMG. He has 32 years of experience performing resource management and performance improvement studies for federal, state, and local agencies across the nation responsible for transportation infrastructure and other public programs. His expertise includes policy development support, strategic and business planning, innovative project finance and delivery, public-private partnerships, road pricing and tolling strategies, asset management, freight planning, operations improvement, performance auditing, and change management. Dornan is a graduate of Rensselaer Polytechnic Institute and is a licensed professional engineer in Florida, New York, Pennsylvania, Texas, and Virginia. 